\title{
Terapia złożona w nadciśnieniu tętniczym - połączenie perindoprilu, amlodipiny i indapamidu
}

\author{
Combination therapy in hypertension: a fixed-dose combination \\ of perindopril, amlodipine and indapamide
}

\author{
Beata Wożakowska-Kapłon \\ I Klinika Kardiologii i Elektroterapii Świętokrzyskiego Centrum Kardiologii w Kielcach \\ Wydział Lekarski i Nauk o Zdrowiu Uniwersytetu Jana Kochanowskiego w Kielcach
}

\section{Streszczenie}

Nadciśnienie tętnicze jest jedną z epidemiologicznie najważniejszych przyczyn zgonów na świecie. Jednocześnie częstość jego występowania stale się zwiększa. Skuteczna kontrola ciśnienia tętniczego odgrywa kluczową rolę w obniżaniu ryzyka sercowo-naczyniowego i śmiertelności ogólnej. Niestety, w Polsce większość chorych nie osiąga docelowych wartości ciśnienia tętniczego. Poprawę w tym zakresie można uzyskać, stosując leki złożone. W niniejszym artykule, na podstawie zaprezentowanego przypadku klinicznego, omówiono korzyści ze stosowania skojarzonej terapii hipotensyjnej, w tym w szczególności połączenia perindoprilu z amlodipiną i indapamidem.

Słowa kluczowe: nadciśnienie tętnicze, terapia, leki złożone, amlodipina, perindopril, indapamid

Folia Cardiologica 2018; 13, 1: 35-38

\section{Wstęp}

Nadciśnienie tętnicze należy do najważniejszych i najbardziej rozpowszechnionych czynników ryzyka sercowo-naczyniowego. Jak wykazano w badaniu INTERHEART, nadciśnienie tętnicze zwiększa prawdopodobieństwo wystąpienia zawału serca niemal 2-krotnie, stanowiąc jeden z 9 niezależnych czynników ryzyka, odpowiedzialnych łącznie za 90\% ryzyka związanego z czynnikami modyfikowalnymi u mężczyzn i 94\% u kobiet [1]. Oprócz zawału serca nieleczone nadciśnienie tętnicze może prowadzić także do wystąpienia udaru mózgu, niewydolności serca, migotania przedsionków, chorób aorty i tętnic kończyn dolnych oraz przewlekłej choroby nerek. Jednocześnie w Polsce obserwuje się istotny wzrost częstości występowania nadciśnienia tętniczego w populacji osób dorosłych — od
29\% w 2002 roku (wg danych z badania NATPOL) [2] do 43\% w 2014 roku (wg wyników badania WOBASZ II) [3].

Głównym celem leczenia chorych na nadciśnienie tętnicze jest skuteczne obniżenie wartości ciśnienia, niezależnie od rodzaju zastosowanej terapii hipotensyjnej, ponieważ najsilniejszym predyktorem zdarzeń sercowo-naczyniowych i zgonu w tej populacji jest brak kontroli wartości ciśnienia tętniczego [4]. Niestety, w Polsce docelowe wartości ciśnienia osiąga jedynie co czwarty pacjent z rozpoznanym nadciśnieniem tętniczym [3]. Przyczyną takiego stanu rzeczy może być, z jednej strony, inercja terapeutyczna lekarzy, a z drugiej - niewystarczające stosowanie się pacjentów do zaleceń, w tym pomijanie dawek leków hipotensyjnych (niski compliance). Poprawę w tym zakresie można uzyskać, stosując leki złożone (tzw. single-pill combination [SPC]). 


\section{Złożona terapia hipotensyjna}

W Polsce w ostatnich latach obserwuje się wzrost częstości stosowania SPC do poziomu $12 \%$ wszystkich leków hipotensyjnych. Ciągle jednak złożone leki hipotensyjne są stosowane przez polskich lekarzy około 2-krotnie rzadziej niż w innych krajach europejskich [5]. Dotychczas niski udział SPC w leczeniu nadciśnienia tętniczego w Polsce można było tłumaczyć wyższym kosztem terapii skojarzonej i mniejszym zakresem dawek poszczególnych leków wchodzących w skład preparatów złożonych (a przez to mniejszą elastycznością terapii). Jednak w ostatnich latach liczba dostępnych złożonych preparatów hipotensyjnych istotnie się zwiększyła, co przełożyło się zarówno na szeroki wybór kombinacji poszczególnych leków, jak i dużą rozpiętość ich dawek, dzięki czemu leczenie za pomocą SPC można dostosować do indywidualnej charakterystyki pacjenta. Korzyści z tej terapii obejmują uproszczenie schematu leczenia i poprawę współpracy z chorym (lepszy compliance), możliwość stosowania mniejszych dawek poszczególnych leków (a przez to obniżenie ryzyka wystąpienia działań niepożądanych) oraz szybsze uzyskanie kontroli ciśnienia tętniczego w porównaniu ze stosowaniem monoterapii [5]. Powyższe zalety terapii SPC powodują, że eksperci Polskiego Towarzystwa Nadciśnienia Tętniczego (PTNT) rekomendują stosowanie preparatów złożonych już na wczesnym etapie leczenia hipotensyjnego - i to nie tylko u chorych z nadciśnieniem tętniczym 2. czy 3. stopnia, ale także u części pacjentów z nadciśnieniem tętniczym 1. stopnia, zwłaszcza obciążonych wysokim ogólnym ryzykiem sercowo-naczyniowym [4, 5]. Z kolei, zgodnie z najnowszymi wytycznymi amerykańskimi z 2017 roku [6], leczenie nadciśnienia tętniczego należy rozpoczynać od dwóch leków (w postaci oddzielnych preparatów lub SPC) u wszystkich chorych, u których wartości ciśnienia tętniczego przekraczają 140/90 mm Hg. Terapia złożona za pomocą SPC jest szczególnie przydatna w przypadku pozornie opornego nadciśnienia tętniczego, związanego przeważnie z nieprzestrzeganiem zaleceń terapeutycznych i stanowiącego najczęstszą postać nadciśnienia tętniczego opornego.

\section{Opis przypadku}

Prezentowany przypadek dotyczy 47-letniego, aktywnego zawodowo mężczyzny z nadciśnieniem tętniczym 2. stopnia, rozpoznanym w trakcie badań okresowych. Ponadto u pacjenta stwierdzono nadwagę (wskaźnik masy ciała [BMI, body mass index] $29 \mathrm{~kg} / \mathrm{m}^{2}$ ) i hiperlipidemię mieszaną. Pozostałe podstawowe parametry laboratoryjne, w tym współczynnik filtracji kłębuszkowej (GFR, glomerular filtration rate), jonogram i glikemia na czczo, były prawidłowe. W elektrokardiogramie (EKG) opisano rytm zatokowy, bez cech przerostu mięśnia lewej komory. Lekarz medycyny pracy zalecił modyfikację stylu życia, leczenie ramiprilem w dawce $10 \mathrm{mg} /$ dobe i hydrochlorotiazydem w dawce $25 \mathrm{mg} /$ dobę (oba leki podawane rano) oraz atorwastatyną. Po miesiącu leczenia wartości w domowych pomiarach ciśnienia tętniczego wynosiły średnio 152/86 mm Hg, w związku z czym lekarz medycyny pracy dołączył do terapii amlodipine $w$ dawce $10 \mathrm{mg} /$ dobę (podawana wieczorem). Po kolejnym miesiącu leczenia obserwowano pewne zmniejszenie wartości ciśnienia mierzonego w godzinach porannych (ze znacznymi ich wahaniami od 126/74 mm Hg do, maksymalnie, 161/83 mm Hg), przy utrzymujących się podwyższonych wartościach ciśnienia w pomiarach wieczornych (średnio 153/84 mm Hg). Z tego powodu pacjent zgłosił się do poradni specjalistycznej. Wykonano tam badanie echokardiograficzne, w którym stwierdzono nieznacznie powiększony lewy przedsionek, bez przerostu mięśnia lewej komory i bez innych istotnych odchyleń. Wynik testu w kierunku mikroalbuminurii był ujemny. Dotychczasowe leczenie hipotensyjne zastąpiono SPC w postaci preparatu złożonego perindoprilu (w dawce $8 \mathrm{mg}$ ), amlodipiny (w dawce $10 \mathrm{mg}$ ) i indapamidu (w dawce 2,5 mg). Po miesiącu leczenia wartości ciśnienia tętniczego w pomiarach domowych wynosiły średnio 132/74 mm Hg. Przeprowadzono całodobową rejestrację wartości ciśnienia tętniczego (ABPM, ambulatory blood pressure monitoring), potwierdzając skuteczną kontrolę ciśnienia, ze średnimi dobowymi wartościami 127/72 mm Hg i zachowanym nocnym spadkiem ciśnienia (profil typu dipper).

\section{Omówienie}

Opisany przypadek jest typowym przykładem pozornie opornego nadciśnienia tętniczego. Na pierwszy rzut oka leczenie hipotensyjne zaordynowane przez lekarza medycyny pracy mogłoby się wydawać zgodne z obowiązującymi zaleceniami PTNT; pacjentowi z nadciśnieniem tętniczym 2. stopnia zalecono wyjściowo dwa leki hipotensyjne, w tym lek hamujący układ renina-angiotensyna-aldosteron (RAA), a w związku z brakiem kontroli wartości ciśnienia do terapii dołączono trzeci lek hipotensyjny. Chory przyjmował zatem trzy leki hipotensyjne (w tym jeden lek diuretyczny) w pełnych dawkach. Czy w tym przypadku nie byłoby zatem uzasadnione rozpoznanie nadciśnienia tętniczego „prawdziwie” opornego? Czy chory ten nie wymagał dalszej diagnostyki, na przykład w kierunku wtórnych przyczyn nadciśnienia?

Jakie mogły być przyczyny nieskuteczności leczenia hipotensyjnego w tym przypadku? Po pierwsze, inhibitor konwertazy angiotensyny (ACE, angiotensin-converting enzyme), na jaki lekarz zdecydował się początkowo, tj. ramipril, choć niewątpliwie doskonale przebadany i preferowany zwłaszcza w przypadkach powikłanego nadciśnienia tętniczego (np. u pacjentów z niewydolnością serca, chorobą wieńcową czy wysokim ogólnym ryzykiem sercowo-na- 
czyniowym), charakteryzuje się krótkim czasem działania i nie zapewnia całodobowej kontroli wartości ciśnienia. Do inhibitorów ACE, których efekt hipotensyjny utrzymuje się przez 24 godziny, należą perindopril i lisinopril [4, 5].

Po drugie, za nietrafny należy uznać wybór hydrochlorotiazydu jako drugiego leku przeciwnadciśnieniowego u pacjenta z zespołem metabolicznym. Zgodnie z wytycznymi PTNT pierwszym skojarzeniem z wyboru u takiego chorego powinno być połącznie leku blokującego układ RAA z neutralnym metabolicznie antagonistą wapnia [4]. W przypadku niezadowalającej kontroli ciśnienia tętniczego kolejnym krokiem byłoby naturalnie dołączenie leku moczopędnego, przy czym preferowane powinny być substancje tiazydopodobne (indapamid, chlortalidon), które cechują korzystniejszy profil metaboliczny i większa siła działania w porównaniu z hydrochlorotiazydem [4].

I wreszcie, po trzecie, dawkowanie leków hipotensyjnych 2 razy/dobę doprowadziło najprawdopodobniej do pomijania wieczornej dawki amlodipiny, o czym moga świadczyć duże wahania porannych wartości ciśnienia w prezentowanym przypadku. Chronoterapia nadciśnienia tętniczego, polegająca na wieczornym podawaniu leków hipotensyjnych, powinna dotyczyć pacjentów, u których w ABPM stwierdzono brak nocnego spadku ciśnienia (profil typu non-dipper) [4]. W pozostałych przypadkach zaleca się stosowanie wszystkich leków przeciwnadciśnieniowych w godzinach porannych.

W opisywanym przypadku do poprawy kontroli ciśnienia tętniczego wystarczyła zamiana leków w obrębie już stosowanych grup, bez konieczności intensyfikacji terapii i dołączania kolejnych środków hipotensyjnych. W omawianym przypadku zamiana kilku, dawkowanych 2 razy/ /dobę, leków na jeden preparat złożony prawdopodobnie zwiększyła compliance u aktywnego zawodowo mężczyzny. Ponadto do poprawy kontroli ciśnienia tętniczego przyczyniły się również najpewniej zamiana krótkodziałającego ramiprilu na długodziałający perindopril oraz słabszego hydrochlorotiazydu na silniejszy indapamid. Ta ostatnia modyfikacja powinna również przynieść korzyści odległe, zważywszy na współistniejące zaburzenia lipidowe i ryzyko rozwoju cukrzycy typu 2 u pacjenta z zespołem metabolicznym.

\section{Terapia skojarzona perindoprilem, amlodipiną i indapamidem}

Na polskim rynku jest obecnie dostępnych kilka połączeń perindoprilu, amlodipiny i indapamidu różnych producentów, z perindoprilem w dawkach 4 lub $8 \mathrm{mg}$ oraz 5 lub $10 \mathrm{mg}$, amlodipiną w dawkach 5 lub $10 \mathrm{mg}$ oraz indapamidem w dawkach 1,25 lub 2,5 mg.

Efekty stosowania kombinacji tych trzech leków zostały szczegółowo przeanalizowane w wielu badaniach klinicznych. W badaniu ASCOT (Anglo-Scandinavian Cardiac Outcome Trial), w populacji ponad 19 tys. pacjentów z niepowikłanym nadciśnieniem tętniczym i obciążonych dodatkowymi czynnikami ryzyka sercowo-naczyniowego, zastosowanie połączenia amlodipiny z perindoprilem wiązało się z rzadszym występowaniem zdarzeń sercowo-naczyniowych, niższym ryzykiem rozwoju cukrzycy i zmniejszeniem śmiertelności całkowitej w porównaniu ze stosowaniem skojarzenia beta-adrenolityku z diuretykiem tiazydowym [7]. Ponadto amlodipina z perindoprilem skuteczniej obniżały ciśnienie centralne [8]. Z kolei korzyści ze skojarzenia perindoprilu z indapamidem wykazano zwłaszcza u pacjentów po 80. roku życia (w badaniu HYVET [Hypertension in the Very Elderly Trial]) [9], u chorych na cukrzyce ( $w$ badaniu ADVANCE [Action in Diabetes and Vascular Disease: PreterAx and DiamicroN Modified-Release Controlled Evaluation]) [10] oraz u osób po przebytym udarze mózgu lub przemijającym ataku niedokrwiennym (w badaniu PROGRESS [Perindopril Protection Against Recurrent Stroke Study]) [11].

Dostępne są również dowody z badań klinicznych wskazujące na korzyści z jednoczesnego podawania tych trzech leków - w skojarzeniu [12-14]. W badaniu PIANIST (Perindopril-Indapamide plus AmlodipiNe in high rISk hyperTensive patients) skojarzenie perindoprilu, amlodipiny i indapamidu zastosowano u 4731 pacjentów z grup wysokiego lub bardzo wysokiego ryzyka sercowo-naczyniowego, u których kontrola ciśnienia tętniczego uzyskana dzięki dotychczasowemu leczeniu była niezadowalająca (ze średnimi wyjściowymi wartościami ciśnienia w całej grupie wynoszącymi 161/94 mm Hg). Po 4 miesiącach stosowania połączenia tych trzech leków stwierdzono istotne obniżenie wartości ciśnienia tętniczego - średnio o $28 \mathrm{~mm} \mathrm{Hg}$ (w przypadku ciśnienia skurczowego) i $14 \mathrm{~mm} \mathrm{Hg}$ (w przypadku ciśnienia rozkurczowego) do wartości 132/80 mm Hg [13]. Z kolei do badania PETRA włączono ponad 11 tys. chorych z nadciśnieniem tętniczym (trwającym średnio 9,5 roku), u których dotychczasową terapię hipotensyjną zamieniano na SPC pod postacią skojarzenia perindoprilu, amlodipiny i indapamidu (w indywidualnie dobieranych dawkach). Wyjściowe wartości ciśnienia tętniczego wynosiły 157/92 mm Hg. Po 3 miesiącach terapii ciśnienie skurczowe obniżyło się średnio o $25 \mathrm{~mm} \mathrm{Hg}$, a rozkurczowe - średnio o $11 \mathrm{~mm} \mathrm{Hg}$. Co ciekawe, obserwowano również istotną redukcję stężeń cholesterolu całkowitego, cholesterolu frakcji lipoprotein o niskiej gęstości (LDL, low-density lipoprotein), triglicerydów oraz glikemii na czczo [14].

\section{Podsumowanie}

Podsumowując, zastosowanie połączenia perindoprilu, amlodipiny i indapamidu jest zgodne z zaleceniami PTNT dotyczącymi zasad kojarzenia grup leków hipotensyjnych, 
umożliwia skuteczną redukcję ciśnienia tętniczego, zapewnia całodobowy efekt hipotensyjny i charakteryzuje się korzystnym profilem metabolicznym oraz udowodnionym działaniem narządowoprotekcyjnym.

\section{Konflikt interesów}

Honoraria za wykłady dla firm: Egis, Krka, MSD, Mylan, Servier.

\section{Abstract}

Hypertension is one of the epidemiologically most important causes of death in the world. At the same time, its incidence is constantly increasing. Effective control of blood pressure plays a key role in reducing cardiovascular risk and overall mortality. Unfortunately, the majority of Polish patients do not reach the target blood pressure. Improvements in this area can be obtained by using fixed-dose combination drugs. This article, on the basis of the presented clinical case, discusses the benefits of combined antihypertensive therapy, in particular the fixed-dose combination of perindopril with amlodipine and indapamide.

Key words: arterial hypertension, therapy, complex drugs, amlodipine, perindopril, indapamide

Folia Cardiologica 2018; 13, 1: 35-38

\section{Piśmiennictwo}

1. Yusuf S, Hawken S, Ônpuu S, et al. Effect of potentially modifiable risk factors associated with myocardial infarction in 52 countries (the INTERHEART study): case-control study. The Lancet. 2004; 364(9438): 937-952, doi: 10.1016/s0140-6736(04)17018-9.

2. Zdrojewski T, Bandosz P, Szpakowski P. Ocena wybranych problemów dotyczących rozpowszechnienia i terapii nadciśnienia tętniczego w Polsce na podstawie badania NATPOL-PLUS. W: Postępy w nefrologii i nadciśnieniu tętniczym. Vol II. Medycyna Praktyczna, Kraków 2002: 11-15.

3. Drygas W, Niklas AA, Piwońska A, et al. Multi-centre National Population Health Examination Survey (WOBASZ II study): assumptions, methods, and implementation. Kardiol Pol. 2016; 74(7): 681-690, doi: 10.5603/KP.a2015.0235, indexed in Pubmed: 26620680.

4. Tykarski A, Narkiewicz K, Gaciong Z, et al. Zasady postępowania w nadciśnieniu tętniczym - 2015 rok. Wytyczne Polskiego Towarzystwa Nadciśnienia Tętniczego. Nadciś Tętn Prakt. 2015; 1: 1-70.

5. Tykarski A, Widecka K, Narkiewicz K, et al. Leki złożone w terapii nadciśnienia tętniczego w Polsce. Stanowisko Ekspertów Polskiego Towarzystwa Nadciśnienia Tętniczego oraz Sekcji Farmakoterapii Sercowo-Naczyniowej Polskiego Towarzystwa Kardiologicznego. Kardiol Pol. 2017; 75(12): 1357-1367, doi: 10.5603/kp.2017.0237.

6. Whelton PK, Carey RM, Aronow WS, et al. 2017 ACC/AHA/AAPA/ABC/ /ACPM/AGS/APhA/ASH/ASPC/NMA/PCNA Guideline for the Prevention, Detection, Evaluation, and Management of High Blood Pressure in Adults: Executive Summary: a report of the American College of Cardiology/American Heart Association Task Force on Clinical Practice Guidelines. Hypertension. 2017 [Epub ahead of print], doi: 10.1161/ /HYP.0000000000000066, indexed in Pubmed: 29133354.

7. Dahlöf B, Sever PS, Poulter NR, et al. ASCOT Investigators. Prevention of cardiovascular events with an antihypertensive regimen of amlodipine adding perindopril as required versus atenolol adding bendroflumethiazide as required, in the Anglo-Scandinavian Cardiac Outcomes Trial-Blood Pressure Lowering Arm (ASCOT-BPLA): a multicentre randomised controlled trial. Prevention of cardiovascular events with an antihypertensive regimen of amlodipine add- ing perindopril as required versus atenolol adding bendroflumethiazide as required, in the Anglo-Scandinavian Cardiac Outcomes Trial-Blood Pressure Lowering Arm (ASCOT-BPLA): a multicentre randomised controlled trial. 2005(366): 895-906, indexed in Pubmed: 16154016.

8. Williams B, O'Rourke M. Anglo-Scandinavian Cardiac Outcomes Trial. The Conduit Artery Functional Endpoint (CAFE) study in ASCOT. J Hum Hypertens. 2001; 15(Suppl 1): S69-S73, indexed in Pubmed: 11685915.

9. Beckett N, Peters R, Fletcher A, et al. Treatment of hypertension in patients 80 years of age or older. N Engl J Med. 2008; 358(18): 1887-1898, doi: 10.1056/nejmoa0801369.

10. Patel A, MacMahon S, Chalmers J, et al. ADVANCE Collaborative Group. Effects of a fixed combination of perindopril and indapamide on macrovascular and microvascular outcomes in patients with type 2 diabetes mellitus (the ADVANCE trial): a randomised controlled trial. Lancet. 2007; 370(9590): 829-840, indexed in Pubmed: 17765963.

11. PROGRESS Collaborative Group. Randomised trial of a perindopril-based blood-pressure-lowering regimen among 6105 individuals with previous stroke or transient ischaemic attack. The Lancet. 2001; 358(9287): 1033-1041, doi: 10.1016/s0140-6736(01)06178-5.

12. Páll D, Szántó I, Szabó Z. Triple combination therapy in hypertension: the antihypertensive efficacy of treatment with perindopril, amlodipine, and indapamide SR. Clin Drug Investig. 2014; 34(10): 701-708, doi: 10.1007/s40261-014-0223-0, indexed in Pubmed: 25212574.

13. Tóth K. PIANIST Investigators. Antihypertensive efficacy of triple combination perindopril/indapamide plus amlodipine in high-risk hypertensives: results of the PIANIST study (Perindopril-Indapamide plus AmlodipiNe in high rISk hyperTensive patients). Am J Cardiovasc Drugs. 2014; 14(2): 137-145, doi: 10.1007/s40256-014-0067-2, indexed in Pubmed: 24590580.

14. Ábrahám G, Dézsi CA. The antihypertensive efficacy of the triple fixed combination of perindopril, indapamide, and amlodipine: the results of the PETRA study. Adv Ther. 2017; 34(7): 1753-1763, doi: 10.1007/ /s12325-017-0572-1, indexed in Pubmed: 28646394. 